\title{
THE IMPACT OF GLOBALIZATION ON THE SITUATION AND IMAGE OF UNIFORMED SERVICES AS EMPLOYERS ON THE POLISH LABOUR MARKET
}

\author{
DOROTA KUREK \\ PhD \\ War Studies University, Poland \\ d.kurek@akademia.mil.pl
}

\begin{abstract}
The progressing globalization process is usually considered in economic, economic, socio-cultural, technical, political, demographic, anthropological and migration aspects. However, only an interdisciplinary approach to globalization allows for its full understanding and showing the real impact on i.a. the situation on the labour market. The indicated dimensions correspond directly to the labour market and the changes that take place on it. Globalization has a huge impact on work and employment, including labour market requirements, as well as changes in the perception of work, the value of work and young peopless approach to it. Factors intensifying globalization processes exert different impact on the image of an organisation as an employer, making some organisations more or less desired employers. The uniformed services are an important employer in Poland, due to the number of employees reaching over 330,000 people. The aim of this article is to show the influence of particular dimensions of globalization on the situation of uniformed services in Poland as employers, as well as on the image of these services. The author of the article analysed only selected uniformed services. This article was prepared, among others, on the basis of o the results of empirical tests carried out in 2019 using the diagnostic survey method.
\end{abstract}

KEYWORDS: GLOBALIZATION, IMAGE, UNIFORMED SERVICES, LABOUR MARKET.

For citation: Kurek, D. (2020). The Impact of Globalization on the Situation and Image of Uniformed Services as Employers on the Polish Labour Market. Globalization and Business, №9, pp. 57-69. https://doi.org/10.35945/gb.2020.09.007

\section{INTRODUCTION}

For many years the issue of globalization has been the subject of interest of politicians, scientists, including sociologists and economists, as well as practitioners, including entrepreneurs and social activists. Globalization is a broad and multidimensional term, its very understanding is ideological and far from unambiguous, which means that globalization has its supporters and opponents. However, in recent year debates within which the negative consequences of globalization are analysed have been growing in prominence, these include the consolidation and widening of social inequalities, deepening of poverty, including social changes in the system of values, needs, perception of work and consequently the situation on the labour market. The intention of the author of this article is not an attempt to describe the phenomenon of globalization, but only to show one of the dimensions of globalization - the market dimension, narrowed down only to the issues of the labour market, including the level of wages, unemployment and free movement of workers within the European Union and the impact of these factors on the situation and image of uniformed services as the employers in Poland. The main research problem to which the author of the article sought answers was formulated in the form of a question: how does globalization affect the situation and image of uniformed services in Poland as the employers? For this purpose, the article could not lack an attempt to define the term globalization, show the dimensions of globalization with particular emphasis on the market dimension, present the situation on the Polish labour market in terms of unemployment, wages, migration, as well as data on the number of Police officers, soldiers and civil servants of both these institutions. The article is concluded with the presentation of the results of empirical research on the perception of the image of the Police and military as the employers on the labour market, including the indication of the attributes of both institutions from the point of view of potential future employees, i.e. representatives of the $Z$ generation.

\section{Globalization and the labour market in Poland}

The issue of globalization and its various dimensions is a subject of broad interest. The complexity of this term allows it 
to be used in relation to a number of contrasting phenomena of a multidimensional nature. The term globalization was first used in Germany in 1953 (Rzepka, A., 2014: 151). The Dictionary of the Polish Language defines it as: a process of increasing interdependence and similarities between different countries around the world, resulting from technological progress in the field of goods transport, movement of people and capital, exchange of information (SJP). Economists, in turn, stress the importance of integration processes in relation to different types of markets and economic structures and the reduction of barriers to international trade and the movement of capital (Ohmae, K., 1995: 65.), including workers and knowledge.

J. Bhagwati draws attention to the international migration of workers (Bhargava, V., 2006: 3), A. LevyLivermore stresses the uniformity of management methods and consumption patterns (Levy-Livermore, A., 1998: 23), and $\mathrm{S}$. Charles stresses the growing interpenetration of markets and increasing internationalisation of the production, distribution, marketing and exchange of goods and services (Charles, S., 1996: 47). In the context of the subject matter of this article, an important definition was provided by $B$. Liberska, according to whom globalization is a progressive process of integrating national and regional markets into one global market of goods and services. This process leads to a growing interpenetration and integration of markets (...) (Liberska, B., 2002: 17-18).

In sociological definitions, the authors draw attention to the following aspects of globalization:
- a multitude of connections between states and societies, which leads to the creation of a homogeneous world (McGrew, A., 1992: 28);

- a change in the way of thinking about social life and the place of a human in it (Robinson, R., 1992);

- the emergence of a universal ethic and value system (Robinson, R., 1992);

- reduction of geographical significance of the location of countries and borders, limiting of territorial distance (Scholte, J.A., 2006: 49);

- the disappearance of geographical barriers, intensification of social relations (Goddens, A., 1991: 64).

The phenomenon of globalization in this article will be considered in relation to the labour market in Poland. The labour market is called the place where the allocation of labour force is carried out, social and economic consequences of the functioning of the economy are revealed, as well as employment decisions are made. The competition operating on the labour market determines the flows of employees and their mobility, while the demand and supply for labour is also determined by other factors, such as the demographic situation, professional activity and deactivation of the workforce, the pace of economic growth, structural transformations, changes within enterprises and the availability of employees, including the level of their competence and their adequacy to market needs (Noga, M; Stawicka, K., 2009: 7-8).

The impact of globalization and integration processes on the labour market results in the emergence of capital

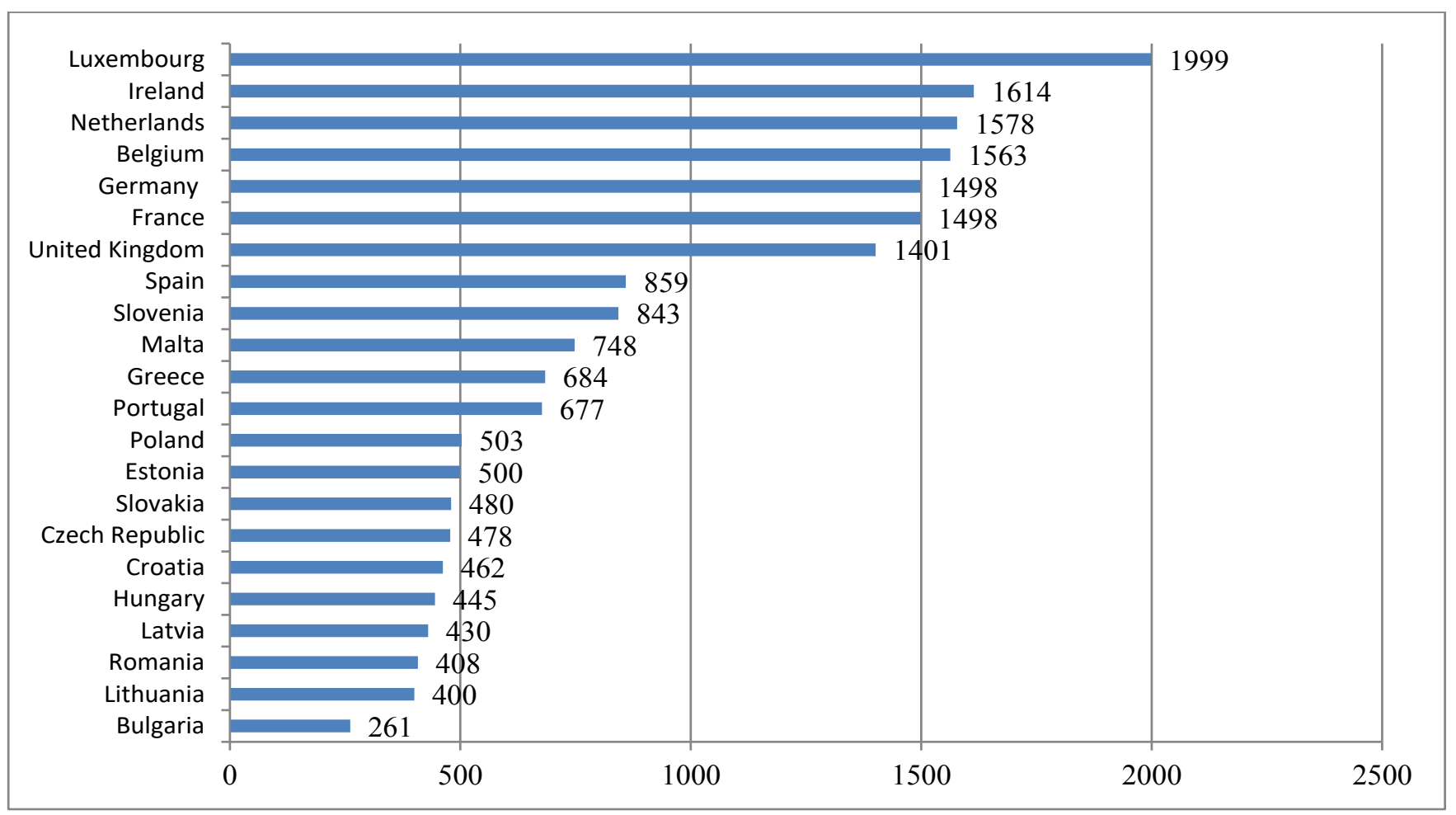

Chart 1. Minimum wage in the EU Member States in 2018 (gross amounts)

Source: Płaca minimalna w krajach Unii Europejskiej. https://gratka.pl/regiopraca/portal/rynek-pracy/zarobki/zdjecieplaca-minimalna-w-krajach-unii-europejskiej-0 (access 25.04.2019). 
mobility on an increasing scale, connected with the disappearance of barriers, a change in the ways of thinking (including attachment to its "Little Homeland»), the system of values, supported also by legal solutions, such as solutions existing on the territory of the European Union, including free movement of workers. The movement includes the right of workers to move and reside, the right of entry and residence of family members and the right to work in another EU Member State and to be treated equally to nationals of that Member State (Swobodny..., 2019). These processes lead to the need to redefine the employment and labour model that existed in many countries so far and which set the trends on the market. This can be seen, inter alia, in relation to the supply of and demand for labour, including difficulties in attracting workers in particular sectors, such as the public sector. Expanding the labour market through Polandss membership in the European Union is a visible
The highest dynamics of wage growth was recorded in Romania - the change in 2015-2018 was $88 \%$. In Poland, in turn, in the indicated years the minimum wage increased by $23 \%$. The dynamics of remuneration shows the pace of changes on the market and, at the same time, disparities between the economic development of the countries.

The level of the offered remuneration, both the minimum and the hourly rate, is another factor influencing the dynamics of migration processes. According to the report Migracje zarobkowe Polaków VIII - maj 2018 (Labour Migration of Poles VIII - May 2018), in 2018 one of the most popular destinations of migration of Poles were: Germany (31\%), the Netherlands (15\% increase by 6 p.p.), Great Britain (6\% decrease by 13 p.p.), Austria (2\%), Norway (2\%) and Spain (1\%). In the group of factors encouraging economic migration, the most important is still the level of income abroad (82\%), higher standard of living (36\%), better social conditions

Table 1. Minimum wage growth in EU countries 2015-2018 (gross amounts)

\begin{tabular}{|c|c|c|c|}
\hline \multirow{2}{*}{ Country } & 2015 & \multirow{2}{*}{ Dynamics } \\
\cline { 2 - 4 } & \multicolumn{2}{|c|}{ Amounts in Euro } & \multicolumn{2}{c|}{8} \\
\hline Romania & 217.50 & 407.86 & $44 \%$ \\
\hline Czech Republic & 331.71 & 477.78 & $42 \%$ \\
\hline Bulgaria & 184.07 & 260.76 & $34 \%$ \\
\hline Hungary & 332.76 & 444.69 & $34 \%$ \\
\hline Lithuania & 300 & 400 & $28 \%$ \\
\hline Estonia & 390 & 500 & $26 \%$ \\
\hline Slovakia & 380 & 480 & $23 \%$ \\
\hline Poland & 409.53 & 502.75 & \multicolumn{2}{|c|}{} \\
\hline
\end{tabular}

Source: compiled on the basis of Eurostat data.

manifestation of the globalization process, both in relation to economic aspects of globalization and sociological aspects. Liberalisation of the labour force flow through the opening of EU labour markets, investments undertaken and legal changes can be considered together on three levels related to: the trend towards equalisation of wages, migration and harmonisation of social systems (Noga, M; Sławicka, K., 2009: 11). The indicated processes on particular levels do not proceed at the same pace, because the tendency to equalise wages in Poland and the EU is much slower in relation to e.g. the scale of migration processes.

When comparing the level of salaries in Poland and in the EU countries, one can observe very large disproportions between the individual EU countries (Chart 1).

Taking into account the minimum wage in the EU countries, in 2018 Poland was ranked 13th, with a salary of EUR 503. The European market leader is Luxembourg (EUR $1,999)$. The group of countries offering remuneration above EUR 1,000 also includes Ireland, the Netherlands, Belgium, France, Germany and the United Kingdom. The lowest wages are paid to employees in Bulgaria, i.e. EUR 261. The pay gap is also worth considering in the context of the wage dynamics, as shown in Table 1 for the years 2015-2018.
(29\%), better prospects for professional development (24\%), or a more favourable tax system (12\%) (Migracje..., 2018). The above-mentioned factors led to the departure of over 2.5 million Poles from Poland by 2018.

Globalization combined with integration also affects the segmentation and duality of the labour market (Noga, M; Sławicka, K., 2009: 11). Segmentation is related to the separation of the private and public labour markets, between which there was a huge difference in terms of wage levels, working conditions, employment stability and labour costs. Segmentation also affects the attractiveness of a given organisation as an employer in the market, which is visible in the effectiveness of recruitment processes. Whereas the labour market dualisation is connected with the phenomenon of division of the labour force into two groups: educated and uneducated workers, as well as mobile and less mobile workers. Educated workers have wider opportunities to compete on the global market, while uneducated workers often remain on the local labour markets. This is evidenced by the results of the research presented in the report Labour Migration of Poles VIII - May 2018, according to which 48\% of respondents with secondary education and $15 \%$ with university education declared their willingness to go abroad 


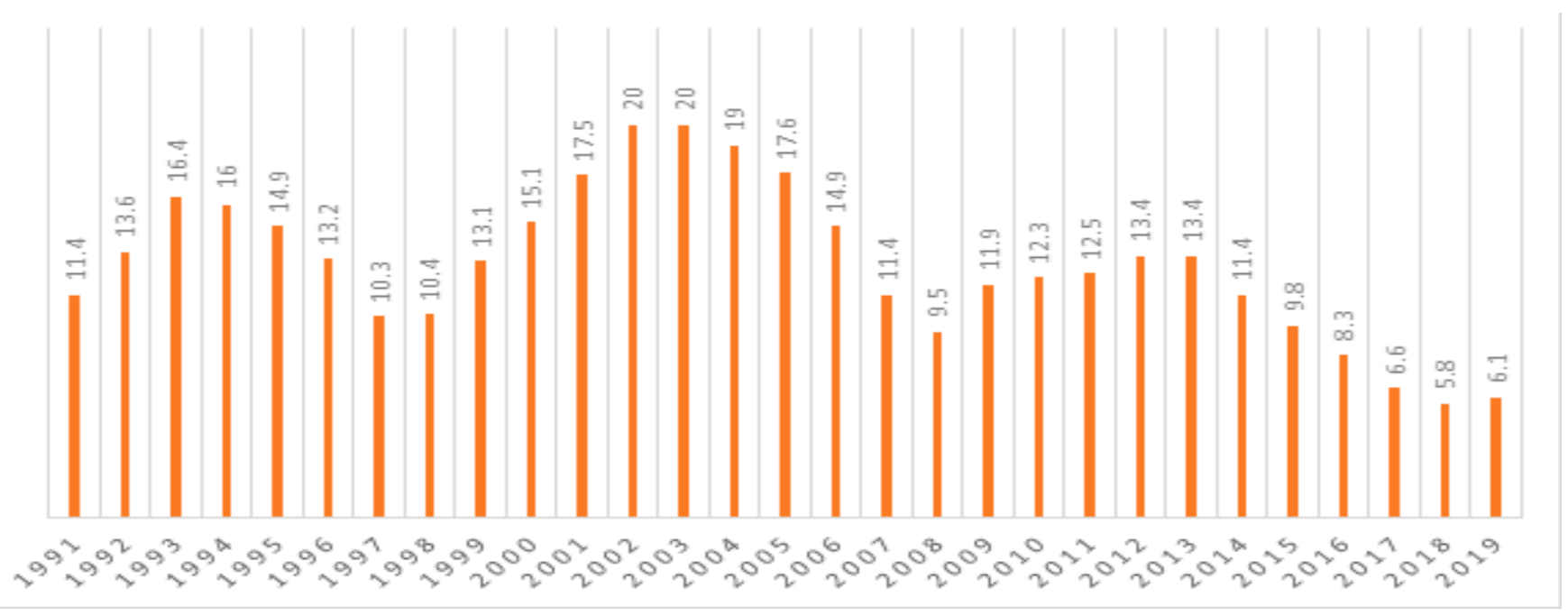

Chart 2. The level of registered unemployment in Poland in the years 1991-2019

Source: Bezrobocie w Polsce w 2019 roku: jak wyglqda sytuacja na rynku pracy?. https://freezl.pl/blog/bezrobocie-wpolsce (access 25.04.2019).

to earn money. Respondents with a lower level of education are less inclined to leave, as evidenced by the willingness to leave declared by $17 \%$ of employees with primary education (Migracje..., 2018).

Integration processes in Europe have also led to the appearance of an unusual phenomenon, because in many cases the attractiveness of wages on foreign markets leads educated Poles to take up paid work below their educational level, but within the framework of higher wages than those offered in Poland within the framework of their learned profession. In many cases, this leads to a situation where there is a shortage of workers with a certain level of education in Poland, despite the fact that theoretically such people exist on the labour market but have taken up employment outside their profession abroad. An additional effect of globalization processes is a change in the stability of employment in the private sector, which leads to a decrease in the sense of social security. Therefore, it can be concluded that the key feature of the labour markets in the era of progressive globalization is the departure from employment stability in favour of the necessity of flexible adjustment to the changing elements of the market, which requires a greater effort from employees, but in return gives greater opportunities for development.

Among the effects of globalization processes, some researchers also include a decline in unemployment in the countries from which workers emigrate. It may be stated that such a situation also occurred in Poland, because before the accession to the $\mathrm{EU}$ the registered unemployment rate reached $20 \%$, and after 2004 a decrease by 1.4 percentage points was recorded in 2005. From 2004 through 2019 unemployment fell by $12.9 \%$ (Chart 2 ).

The reasons for dropping in unemployment cannot be only seen in the migration processes, as the economic recovery in the country also plays an important role.

In conclusion, the globalization process as a multidimensional phenomenon has a significant impact on the situation on the labour market. Emerging migration flows, changes in supply and demand on the market, greater dynamism of market processes are only a few examples illustrating the effects of homogenisation of the world globalization.

\section{Uniformed services in Poland}

The term uniformed services, despite the fact that it has become widely used on a permanent basis and is used both in scientific articles and in non-scientific publications, has not been defined in any of the legal acts regulating the functioning of uniformed formations.

The term (service) can be considered in at least three ways: as work for others, performed with dedication, as activities of public utility institutions, including the Army, or as work performed by employees of public utility institutions or the Army, performed during certain hours as an element of their assigned duties. Therefore, uniformed services are: public entities (public institutions), hierarchical entities (which also translates into the obligation to carry out orders and service assignments), subordinate to superior or central government administration bodies such as ministries, performing tasks specified in legal acts (e.g. laws), tasks aimed at ensuring security and order. Officers of the uniformed services have special powers which enable them to perform specific tasks. The characteristics of uniformed services also include specific attire, the uniforms worn by officers and equipment, including official weapons. The uniformed services are also characterised by the legal form of administration.

The above considerations lead to a reflection that the catalogue of uniformed services is not of a closed nature. Additionally, when analysing the source literature, one can find supporters of narrower and broader catalogues of uniformed services. The representatives of the broad approach are W. Maciejko, M. Rojewski and A. Suławko-Karetko. The authors define the following as uniformed services: Police, SOP (State 
Table 2. Employment in the Police and the Polish Army in the years 2005-2017

\begin{tabular}{|c|c|c|c|c|c|c|}
\hline \multirow{2}{*}{$\begin{array}{l}\text { The uniformed } \\
\text { service }\end{array}$} & \multirow{2}{*}{$\begin{array}{l}\text { Officers } \\
\text { and civil workers }\end{array}$} & 2005 & 2010 & 2015 & 2016 & 2017 \\
\hline & & \multicolumn{5}{|c|}{ in thousands } \\
\hline \multirow{3}{*}{ Police } & Police officers & 100.7 & 97.5 & 98.9 & 100 & 98.8 \\
\hline & Civilian employees in Police & 19.1 & 25.4 & 24.7 & 25 & 24.6 \\
\hline & Total & 119.8 & 122.9 & 123.6 & 125 & 123.4 \\
\hline \multirow{3}{*}{ Army } & Professional soldiers & 77.9* & 95.4 & 96.2 & 98.6 & 101.6 \\
\hline & Civilian Army employees & 52 & 48.1 & 45.5 & 45.3 & 45.6 \\
\hline & Total & 129.9 & 143.7 & 141.7 & 143.9 & 147.2 \\
\hline
\end{tabular}

*the number given is for professional soldiers only. In 2005, in the structures of the Army there were also 5 thousand soldiers of overdue basic military service and 52.1 thousand soldiers of basic military service.

Source: own study based on Mały Rocznik Statystyczny Polski. GUS. Warsaw 2010. pgs. 87, 91 and Mały Rocznik Statystyczny Polski. GUS. Warsaw 2018. pgs. 72, 74.

Defence Services, former BOR), civil and military special services, Army, fire brigade, Border Guard, Customs Service, Prison Service, municipal guards, Forest Guard, National Park Guard, Road Transport Inspectorate, Railway Protection Guard, or MP, etc (Maciejko, W; Rojewski, M; SuławkoKaretko, A., 2011). K. Sławik, in turn, is a supporter of the narrow catalogue and enumerates the following uniformed services: Police, Border Guard, Prison Service, SOP, MP, State Fire Service, Road Transport Inspectorate, special services, Marshalıs Guard and Customs Service (Sławik, K., 2011: 46-169).

Therefore, the definition of uniformed services by M.A. Liwo is justified; it states that the uniformed services are: public entities designated by the legislator with a particular organization - like military ones - subject to the supreme bodies of government administration, carrying out statutory tasks within the framework of public service related to the provision of a specific type of security and order, on the basis of the powers granted and the legal forms of operation of the relevant administration (Liwo, M., 2015: 20).

In the further part of the article the image of two types of uniformed services, such as the Police and the Army, will be presented in the analysis. The choice of the indicated services results both from the number of these formations and their importance as employers in Poland.

The above-mentioned uniformed services in Poland include numerous formations which are the workplace and services for both civil servants and officers. The analysis of data contained in the Small Statistical Yearbook of Poland of 2018 shows that, as at 31 December 2017, there were 200.4 thousand officers serving in the Police and the Army, including 98.8 thousand Police officers and 101.6 thousand professional soldiers (Table 2).

The Police officers) service was supported by 24.6 thousand civilian employees, while the civilian Army employees registered 45.6 thousand. Therefore, there were 70.2 thousand civilian employees working for the Police and the Army in 2017. The exact structure of employment and service is presented in Table 2, showing the changes in the years 2005-2017.

The current structure of employment in relation to the Police does not differ significantly from the data contained in the Statistical Yearbook of 2018. As at 1 January 2019, 98,670 officers were employed in the Police (full-time posts $103,309)$. Therefore, there were 4,636 vacant posts. In 2018 , 4,517 officers were admitted to service in the Police, while at

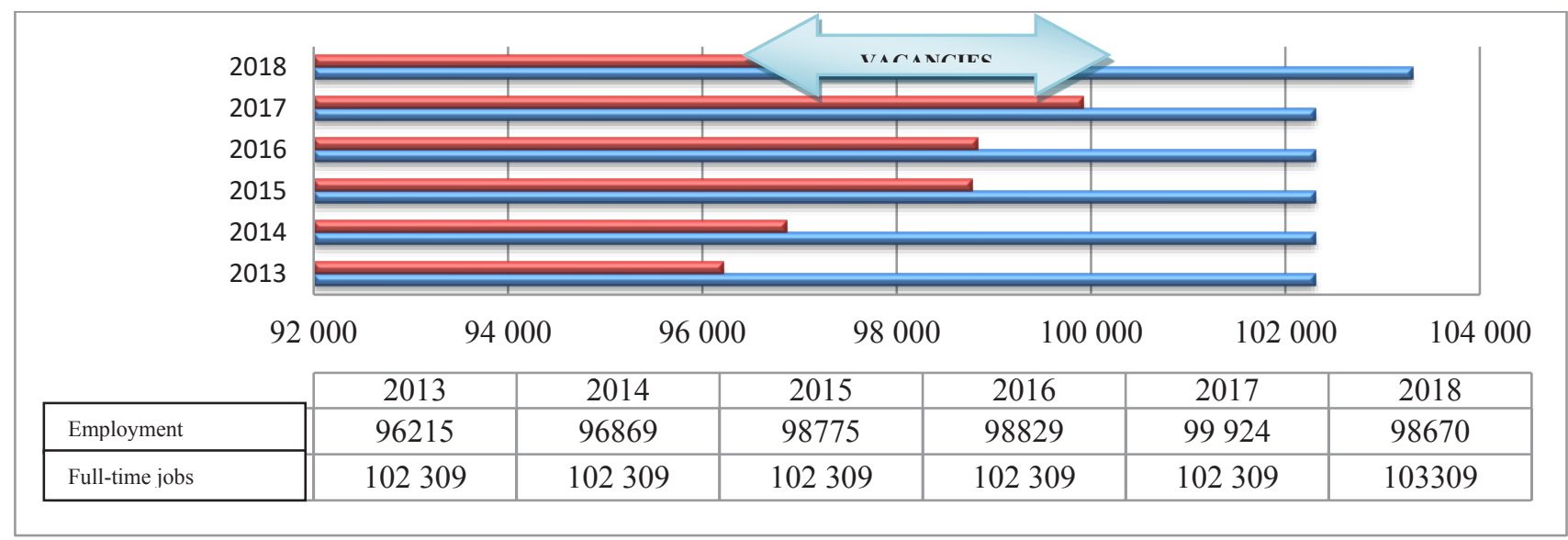

Chart 3. Employment and number of vacancies in the Police

Source:owncalculationsbasedondataavailableathttp://www.info.policja.pl/inf/organizacja/stan-zatrudnienia/49216,Stanzatrudnienia-na-dzien-1 stycznia-2019-roku.html (accessed on 25.04.2019) and data from 2013-2017. 
that time 4,470 officers were dismissed from service. In turn, 11,764 employees worked in the Civil Service Corps (full-time posts $-12,202.5$ ). The work of the Police was also supported by 12,969 (including half-time posts) other employees (fulltime posts - 12,542.3) (Stan..., 2019). Taking-into account only the employment of officers, Chart 3 shows the full-time posts together with the employment status in the Police in 2013-2018, which made it possible to determine the number of vacancies in the Police.

For many years now, the Polish Police have been struggling to recruit candidates for officers. The employment level is additionally reduced by the number of officers dismissed from service each year (In 2017, 4,151 officers were admitted to the service, while 5,364 people were dismissed. In 2016, 5,092 persons were admitted to service in the Police, while in the same year 3,989 officers left the service. In 2015, 3,033 persons were admitted to the Police service. At that time, 3,007 policemen were dismissed from service. A similar situation occurred in $2014-4,075$ persons were admitted to the Police service and 2,983 officers were dismissed. The largest number of officers left in $2013-4,333$ policemen. In 2013, a record number of 5,787 people were admitted to the Police service).

Analysing employment in the Polish Army, the suspension of basic military service and the introduction of the National Reserve Force had a significant impact on the size of the Polish Army. Additionally, on 1 January 2017, the fifth type of armed forces - the Army of Territorial Defence (WOT) was established, whose main objective is to cooperate with operational forces, protect the population against the effects of natural disasters and eliminate those effects, protect property, search and rescue operations, protect human health and life, implement tasks in the field of crisis management, and promote the idea of patriotic education in society (Wojska..., 2019). According to the established concept, by 2021, 17 brigades are planned to be established. Pursuant to the Regulation of the Council of Ministers of 12 December 2018 on the number of persons who may be called up for active military service in 2019 (Journal of Laws of 2018, item 2366), in 2019, WOT may count up to 26 thousand soldiers in reserve. Territorial Defence Forces are not included in the Statistical Yearbook, and they are included by the Ministry of National Defence in the general numerical status of the Army.

Paying attention to the last three years, we can observe an increase in the number of professional soldiers, greater interest in the candidate service and an increase in the number of reserve soldiers (NSR). The personnel status of the Polish Army is likely to increase steadily, according to the Minister of National Defencess announcements, but it is also worth noting the number of professional soldiers who leave the ranks of the Army every year. For example, in 2014, 3,191 soldiers (including 90 officers, 822 non-commissioned officers and 1,760 professional privates) left the Army, in 2015 the number of the military employees living the Army was 3,888 (691 officers, 971 non-commissioned officers and 2,226 professional privates) and in 2016 - about 5.5 thousand soldiers (including 25 generals), and by the third quarter of 2017 4,293 soldiers cased working for the Army (42\% of this number are professional privates). Such high rotation rates result from the size of the Army, although it is surprising that due to the amendment of the pragmatic act in March 2016, which dealt away with the barrier of 12 years of contractual service, such a large number of privates are still leaving the Army.

To sum up, it has not been noted that the Army struggles with the difficulty of recruiting future soldiers into its ranks, which does not contradict the fact that recruitment is constantly being conducted, as evidenced by the offers published on the websites of individual Military Supplementary Command.

Table 3. Average gross remuneration in 2005-2017

\begin{tabular}{|c|c|c|c|}
\hline \multirow{2}{*}{ The uniformed service } & \multirow{2}{*}{ Year } & Officers & Civilian employees \\
\hline & & \multicolumn{2}{|c|}{ Gross remuneration in PLN } \\
\hline \multirow{5}{*}{ Police } & 2005 & 2,931 & 1,879 \\
\hline & 2010 & 4,199 & 2,667 \\
\hline & 2015 & 4,564 & 2,961 \\
\hline & 2016 & 4,748 & 3,129 \\
\hline & 2017 & 5,077 & 3,437 \\
\hline \multirow{5}{*}{ Army } & 2005 & 3,229 & 1,972 \\
\hline & 2010 & 4,049 & 2,913 \\
\hline & 2015 & 4,335 & 3,422 \\
\hline & 2016 & 4,548 & 3,745 \\
\hline & 2017 & 4,962 & 4,090 \\
\hline
\end{tabular}

Source: own study based on Mały Rocznik Statystyczny Polski. GUS. Warsaw 2010. pgs. 87, 91 and Mały Rocznik Statystyczny Polski. GUS. Warsaw 2018. pgs. 72, 74. 


\section{Remuneration in the Police and the Army - and the situation on the labour market in Poland}

The performance of service and work in the Police and the Polish Armed Forces is connected with receiving a monthly salary. The amount of remuneration is an important factor influencing the choice of these institutions as future employers. Table 3 presents the average gross remuneration of Police officers, soldiers and civilian employees of the Police and the Army in the years 2005-2017.

The data in Table 3 refers to the average remuneration, which is a big simplification, since the amount of remuneration is different for a soldier with the rank of a general and for a policeman with the rank of a sergeant. The remuneration is also influenced by the length of service and all kinds of allowances, including the so-called capital city allowance for officers on duty in the capital city of Warsaw. When analysing the changes in the average remuneration of Police officers in the years 2005-2017, one can observe an increase in remuneration by over $73 \%$ (i.e. by PLN 2,146 to be precise). At the same time, the remuneration of civilian employees increased by over $82 \%$ (by PLN 1,558 to be precise). As regards the remuneration of professional soldiers, a significant era of globalization is also the fact that Poles, like other citizens of the European Union, together with the opening of the European labour market after the accession to the EU, may provide work outside the borders of the country. For instance, Poles who speak German can apply for a job in the German Police. In the course of their studies, students receive a monthly salary of EUR 1,200, which is about PLN 5,110, i.e. twice as much as the rate offered to the students in Poland (AMB, 2018). Attractiveness of foreign labour markets, including free movement of workers, is an additional element that has a negative impact on the situation in the Police. According to statistical data, the average salary that Poles receive abroad is EUR 10 gross per hour of work, amounting to EUR 1,680 monthly, which is 7224 in PLN. In 2017, over 2.5 million Poles temporarily resided outside Poland, including there were about 2,241 thousand people living in European countries (by 27 thousand more than in 2016), with the vast majority of them - about 2,121 thousand. - in the EU member states, Among the EU countries, the largest number of Polish emigrants stayed in Great Britain (793 thousand), Germany (703 thousand), the Netherlands (120 thousand) and Ireland (112 thousand) (Informacja..., 2017).

The emigration of Poles influences, among others, the

Table 4. Remuneration in the Police and the Army in comparison with the average remuneration in Poland

\begin{tabular}{|l|c|c|c|}
\hline \multirow{2}{*}{\multicolumn{1}{|c|}{ Entities }} & $\mathbf{2 0 1 5}$ & $\mathbf{2 0 1 6}$ & $\mathbf{2 0 1 7}$ \\
\cline { 2 - 4 } & \multicolumn{3}{|c|}{ Gross remuneration in PLN } \\
\hline Police officers & 4,564 & 4,748 & 5,077 \\
\hline Civilian employees in Police & 2,961 & 3,129 & 3,437 \\
\hline Soldiers & 4,335 & 4,548 & 4,962 \\
\hline Civilian Army employees & 3,422 & 3,745 & 4,090 \\
\hline Poles in general (data from the fourth quarter) & $4,066.95$ & $4,218.92$ & 4516.69 \\
\hline
\end{tabular}

Source: prepared on the basis of Mały Rocznik Statystyczny Polski. GUS. Warsaw 2010. pgs. 87, 91, Mały Rocznik Statystyczny Polski. GUS. Warsaw 2018. pgs. 72, 74 and Komunikaty w sprawie przeciętnego wynagrodzenia zamieszczanych na stronie internetowej Głównego Urzędu Statystycznego Polski, https://stat.gov.pl/sygnalne/komunikaty-i-obwieszczenia/ lista-komunikatow-i-obwieszczen/komunikat-w-sprawie-przecietnego-wynagrodzenia-w-iv-kwartale-2015-r-,271,11.htm/ (access 25.04.2019).

increase of over 53\% (by PLN 1,733) and of civilian employees of the Army by over $107 \%$ (by PLN 2,118) was also noted.

In conclusion, although the remuneration of Police officers has increased in recent years due to the nature of their service (type of service, danger, as well as image), the data presented in the yearbooks, due to averages and gross values, differ significantly from reality. A reasonable example is the remuneration received by students (officers on basic courses), which amounts to PLN 1,950 net. Whereas the average net remuneration of a policeman at the initial stage of her/his career amounts to PLN 3,024 (Zarobki..., 2018). In turn, the increase in the salary of soldiers is lower than in the case of Police officers, while the highest increase was recorded in relation to the salary of civilian employees of the Army, which means that currently a civilian employee of the Army earns on average PLN 653 more than a civilian employee of the Police.
Considering the remuneration offered to Police officers, soldiers and civil servants of both these institutions, in isolation from the situation on the labour market in Poland, does not allow to show the real disproportions. It is therefore justified to show the amount of remuneration in the Police and the Army against the background of the average remuneration in Poland (Table 4.).

The analysis of Table 4 shows that the average remuneration in Poland in 2017 was only PLN 560.31 lower than the remuneration of Police officers and PLN 445.31 lower than the remuneration of soldiers. In turn, with regard to civilian employees, on average Police employees would receive PLN 1,079.69 more on the labour market, while the Army would receive PLN 426.69 more.

An additional element important in the context of the situation of uniformed services on the labour market in the 


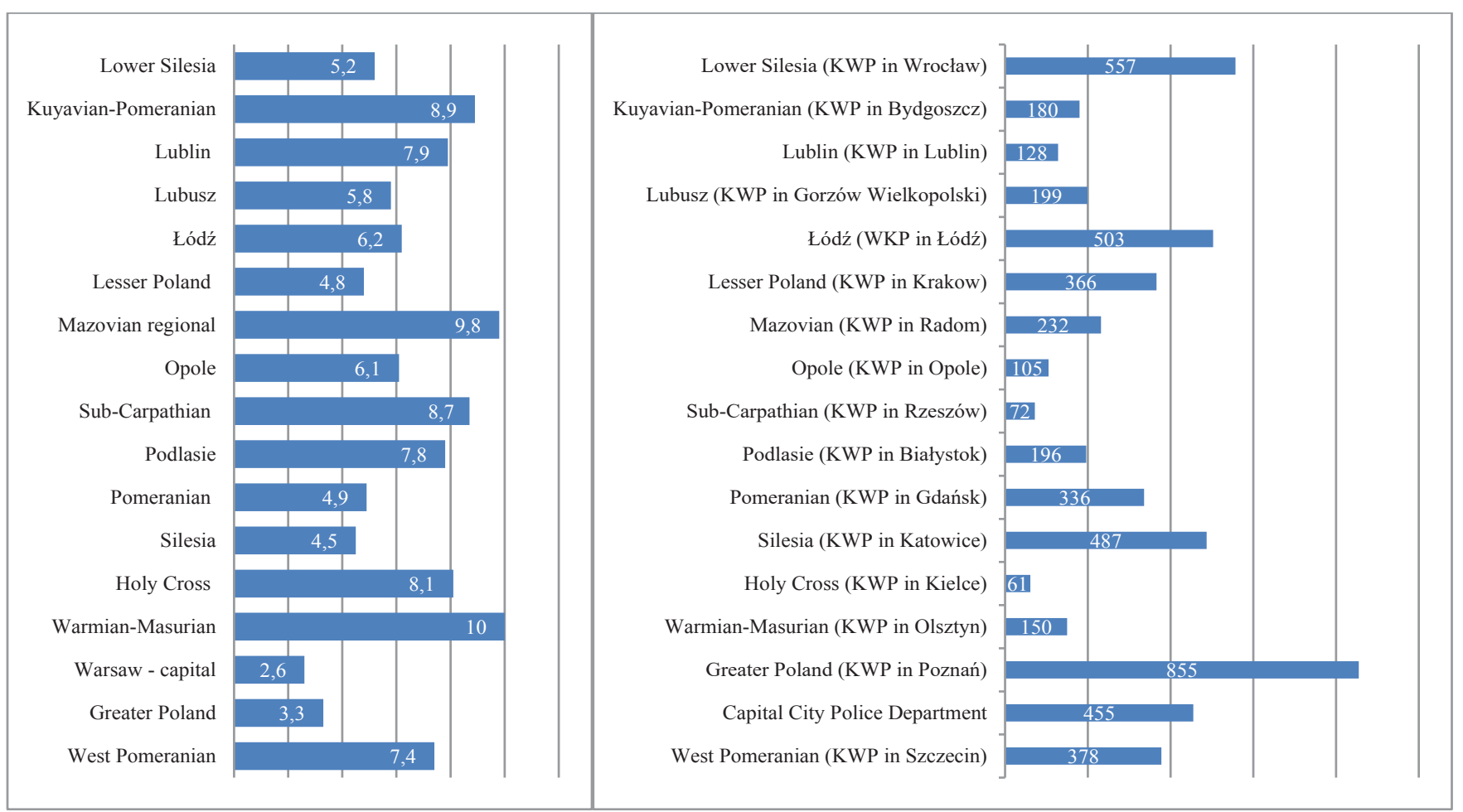

Chart 4. Registered unemployment rate as at the end of June 2018 and the number of vacancies in the Police as at the end of the first quarter of 2018.

Source: $\quad$ http://stat.gov.pl/obszary-tematyczne/rynek-pracy/bezrobocie-rejestrowane/bezrobotni-zarejestrowani-istopa-bezrobocia-stan-w-koncu-czerwca-2018-r-,2,71.html (downloaded 09.08.2018) and work prepared on the basis of http:// nszzp.wroclaw.pl/index.php/2018/06/16/znowu-nas-mniej-6283-wakaty-na-1-czerwca-dolnoslaskie-108) (downloaded 12.07.2018).

decrease of the unemployment rate in Poland. According to the data of the Central Statistical Office, in March 2019 the registered unemployment rate in Poland amounted to $5.9 \%$, which in comparison to previous years (data of the Central Statistical Office since 1990) is the lowest value (Stopa..., 2019). Comparing the unemployment rate in a given voivodeship with the number of vacancies in particular garrisons, it can be noted that in the case of Lower Silesian, Silesian Voivodeships and the capital city of Warsaw, a low unemployment rate may have a significant impact on the difficulties in obtaining candidates for officers (Chart 4.).

The lowest unemployment rate recorded in Warsaw, oscillating at the level of $2.6 \%$, is primarily related to the attractiveness of the labour market in the capital city, where the (average) salary in 2018 amounted to PLN 6,000. Every fourth employee earned in this period below PLN 4,200, while 25\% earned more than PLN 9,233 (Sutor, A., 2018). It is therefore reasonable to state that the amount of remuneration offered to candidates in the Police at the beginning of their service is in no way attractive in relation to the labour market in the capital city, which generates difficulties in attracting candidates for service from this region and others.

In conclusion, in recent years, there have been changes in the salaries of officers and civil servants in the Police and the Army. However, taking into account the market rates of salaries offered by private organisations, in many cases uniformed services are not able to compete with the indicated organisations in terms of the level of remuneration. Therefore, it is a significant factor weakening the position of uniformed services as attractive employers on the Polish labour market.

\section{The image of uniformed services as employers in Poland - results of the survey}

Public and private sector organisations do not operate in a vacuum. Their functioning is influenced by many factors (forces), both of a direct and indirect nature (Figure 1).

The indicated factors include economic (including globalization), technological, socio-cultural, political and natural aspects. All of the above factors, to a greater or lesser extent, contribute to the success or difficulty of an organisation in the market, while at the same time affecting the image of the organisation as an employer.

An organisationss image can be defined as a subjective image created in the mind of an individual recipient (Skowronek, I., 2012: 29), resulting from a summary evaluation of all types of transactions, experiences with the company. The feelings and experiences contained in the memory of the recipients are transformed into images that correspond to the personal values of the individual (Nguyen, N; LeBlanc, G., 1998: 52-65). Therefore, the words of D.J. Boorstin, who 


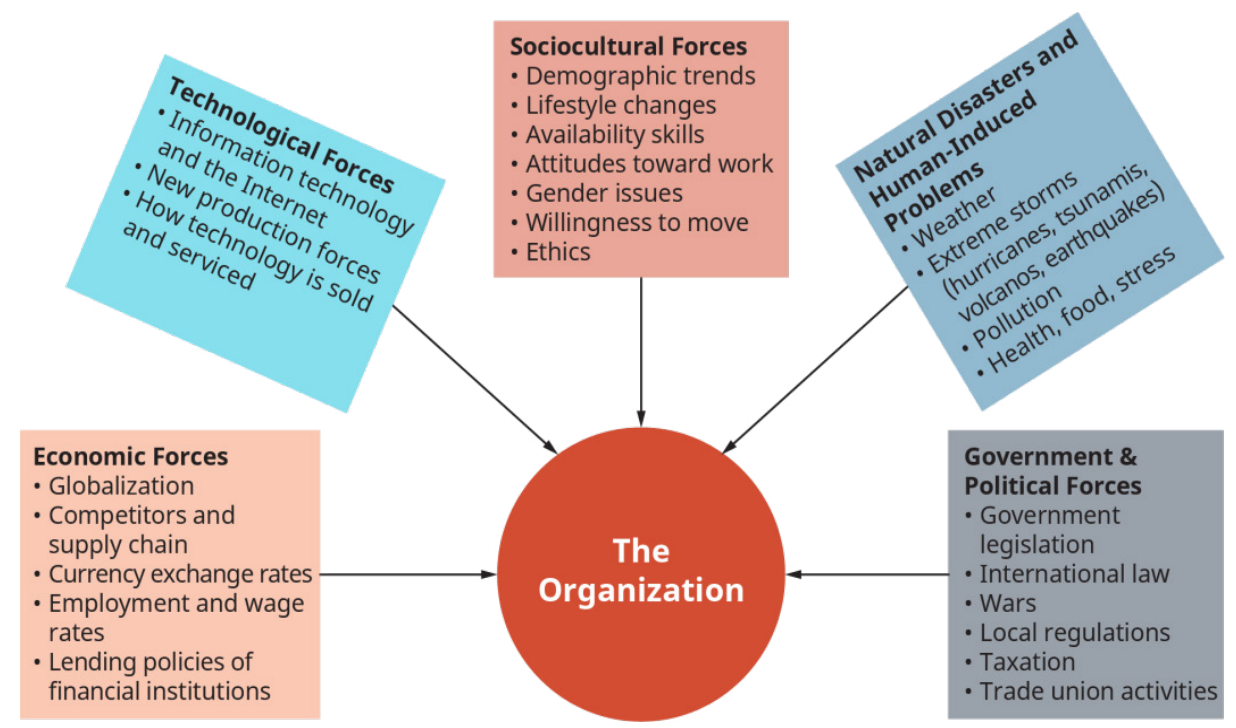

Figure 1. Factors affecting organisations

Source: The Organizationss External Environment. https://cnx.org/contents/w6yyq31c@2.11:nGufNJoq@2/4-1-TheOrganization-s-External-Environment (downloaded 04.05.2019).

emphasises the ambiguity of the image, fluctuating between imagination and reason, expectations and reality, are justified (Boorstin, D.J., 1961: 193). The image of an organisation, which is its image among people, is constantly changing. The change is influenced by the shifting environment, changing needs of individuals and alternating trends. The fragmentary images of individual individuals summing up translate into the general image of an organisation in the environment (the so-called socio-political perspective (Waszkiewicz, A., 2011: 25)), in the local community, or on an international scale (the so-called global image). The global image of an organization refers to the general perception of an organization on the market, and is, among other things, the result of the adopted image strategy.
The image of an organization, defined as a commonly existing opinion on the organization (Bernstein, D., 1984: $125)$, is a subjective image whose quality is affected by the perception of the recipient (cognitive abilities) and his internal feelings - impressions, emotions. The image translates into the basis for the organisation, which may result in acceptance and support for the activities, which in the case of uniformed services is of great importance in the social context, as well as the willingness to work in the organisation, considered as an attractive employer.

The issue of shaping the image of an organisation as an attractive employer by choice is described as employer branding. This term is defined as: the process of creating value

The amount of remuneration offered Location of the workplace

Working atmosphere

Opportunity for professional development

Working time flexibility

Employment stability

Ability to maintain a work-life balance

Possibility to fulfil passions by performing work

Interesting tasks to be performed at work

Company image

Form of employment

Working conditions

Prestige of the practised profession

Investment in employee competence development

Types of social benefits offered

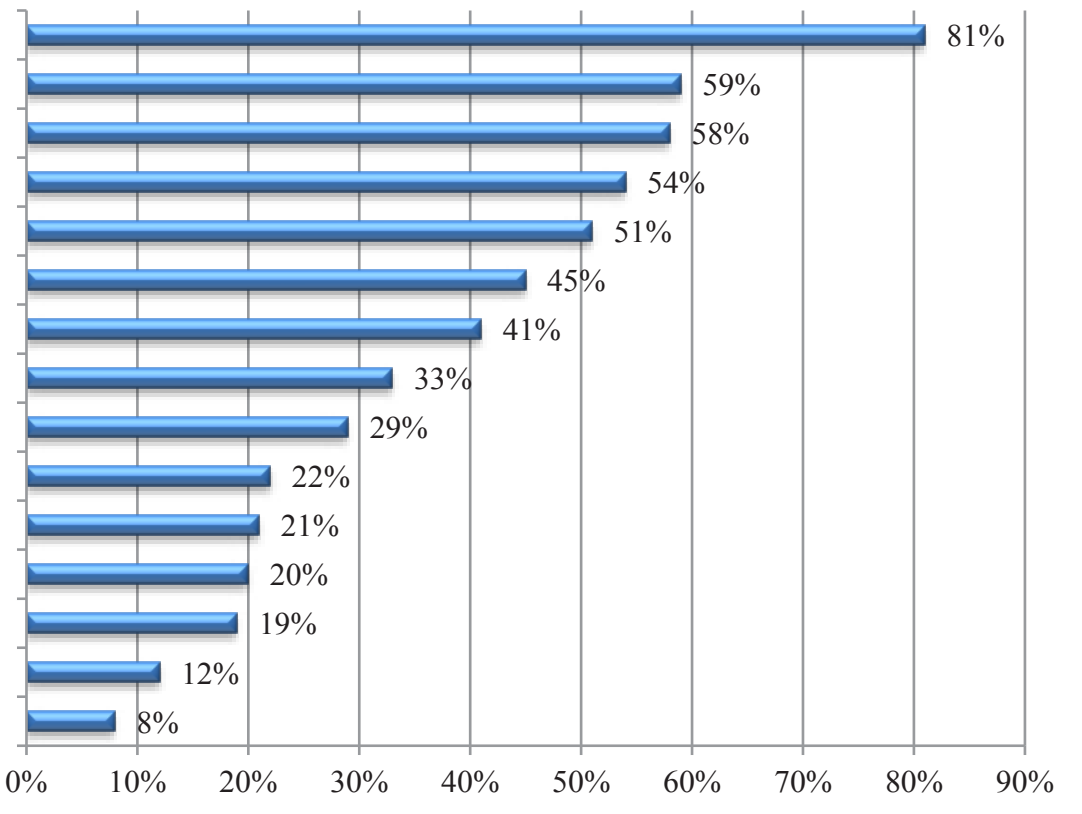

Chart 5. Factors most influencing the choice of future employer 


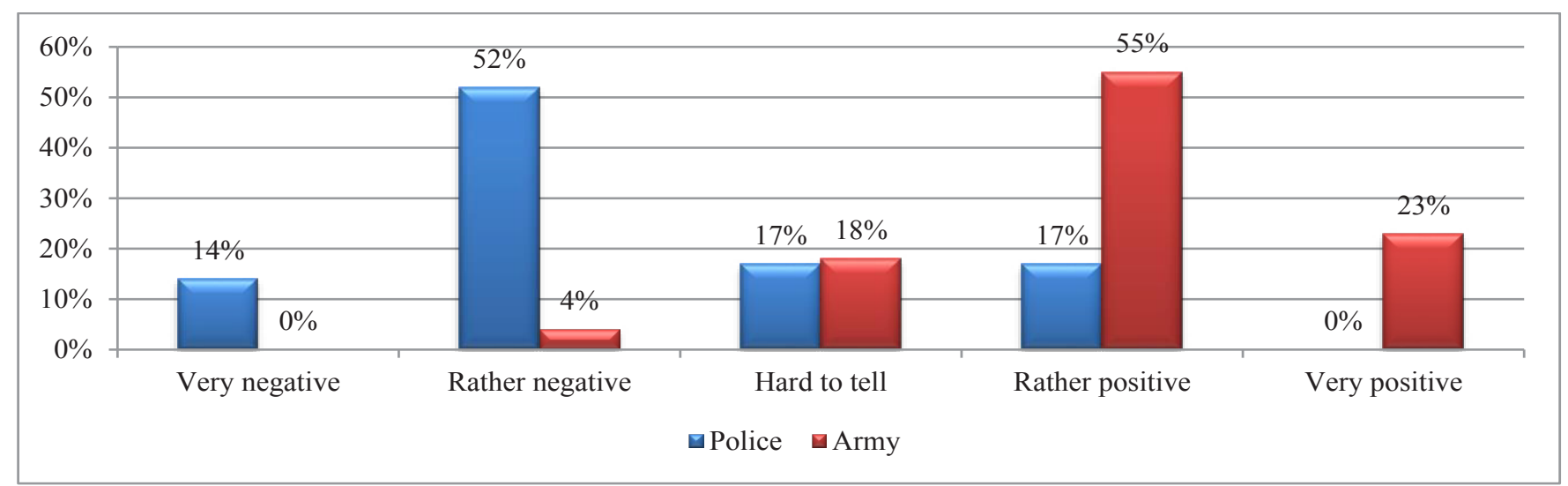

Chart 6. Assessment of the image of the police and Army

for stakeholders, which arises as a result of the organisation is strong employer brand (Wojtaszczyk, K., 2012: 86). In order for an organisation to be defined as an employer of choice, it must be trustworthy, including offering an attractive job in which the employee has the opportunity to satisfy his or her needs. Being an employer of choice is therefore the result of the sum of anticipated benefits that potential employees perceive and which are the result of the organisationss image on the market. The employerss attractiveness on the market is shaped by such factors as: economic values (e.g. remuneration level), social values (including working atmosphere, employment security) or development opportunities. The organisationss legitimacy with a strong employerss brand allows it to attract candidates to work or reduce the level of fluctuations, which, however, requires consistency in action, including assigning the personal function of the organisation with a strategic rank.

In the course of the research, the image of two uniformed services was analysed: Police and Army as employers on the Polish labour market. Empirical research using the method of a diagnostic survey carried out using the questionnaire technique was conducted in January 2019 on a sample of 100 people. The group of respondents included $59 \%$ of women and $41 \%$ of men aged from 18 to 35 . The selection of the research sample was purposeful, as the opinions of potential candidates for service in both institutions were analysed. The aim of the research was to identify the image of the
Police and the Army as employers in Poland, including the identification of attractive factors of these organisations as a potential workplace.

The choice of an organisation as a future employer is determined by many factors, including the willingness to satisfy the existing needs. Such a possibility becomes a key aspect encouraging to make an effort to apply for a job in a given organisation. Figure 5 shows the factors that, according to the respondents, determine the choice of a future employer to the greatest extent.

According to the respondents, the most important factors influencing the choice of future employer include: the level of offered remuneration (81\%), location of the workplace (59\%), working atmosphere (58\%), possibility of professional development (54\%), flexibility of working time (51\%) and stability of employment (41\%). In turn, $22 \%$ of respondents indicated the image of the organisation, while only $19 \%$ of respondents chose the prestige of their profession. Therefore, it can be stated that the key factor (which is also confirmed by nationwide surveys) for employees is still the issue of the amount of remuneration, with the simultaneous importance of the location of the workplace - which in many cases results from the lack of willingness to change the place of residence, and therefore low mobility of employees.

In the further part of the research, the general image of the Police and the Army was analysed (Chart 6).

In the opinion of respondents, the military $(78 \%$ of

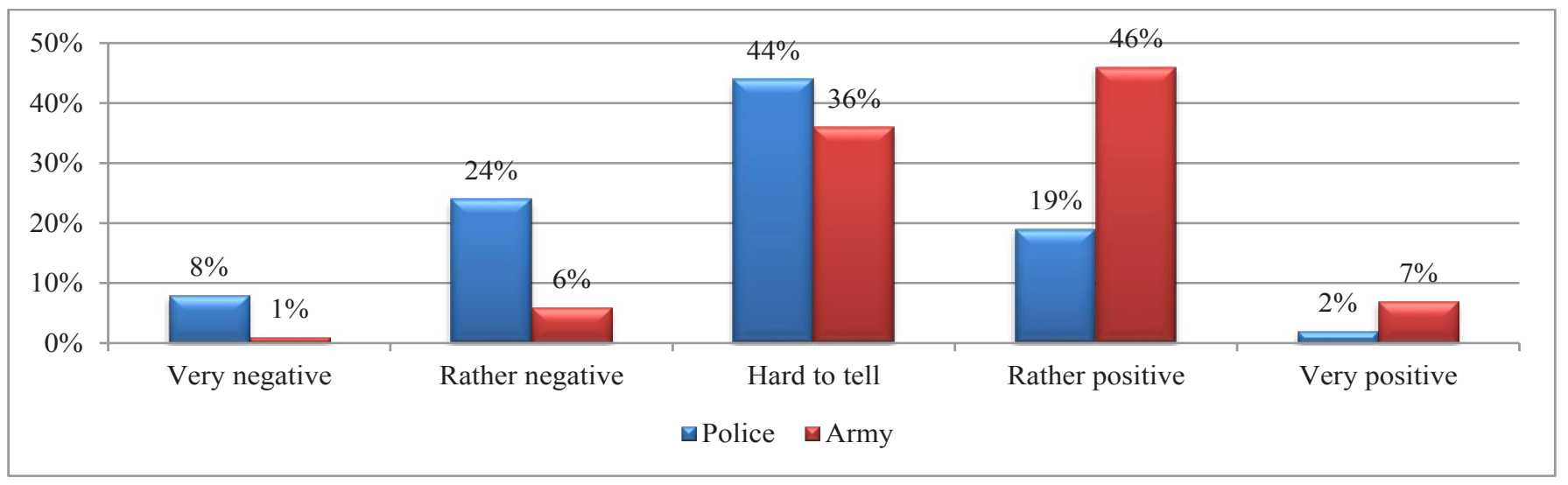

Chart 7. Police and military as employers on the labour market 


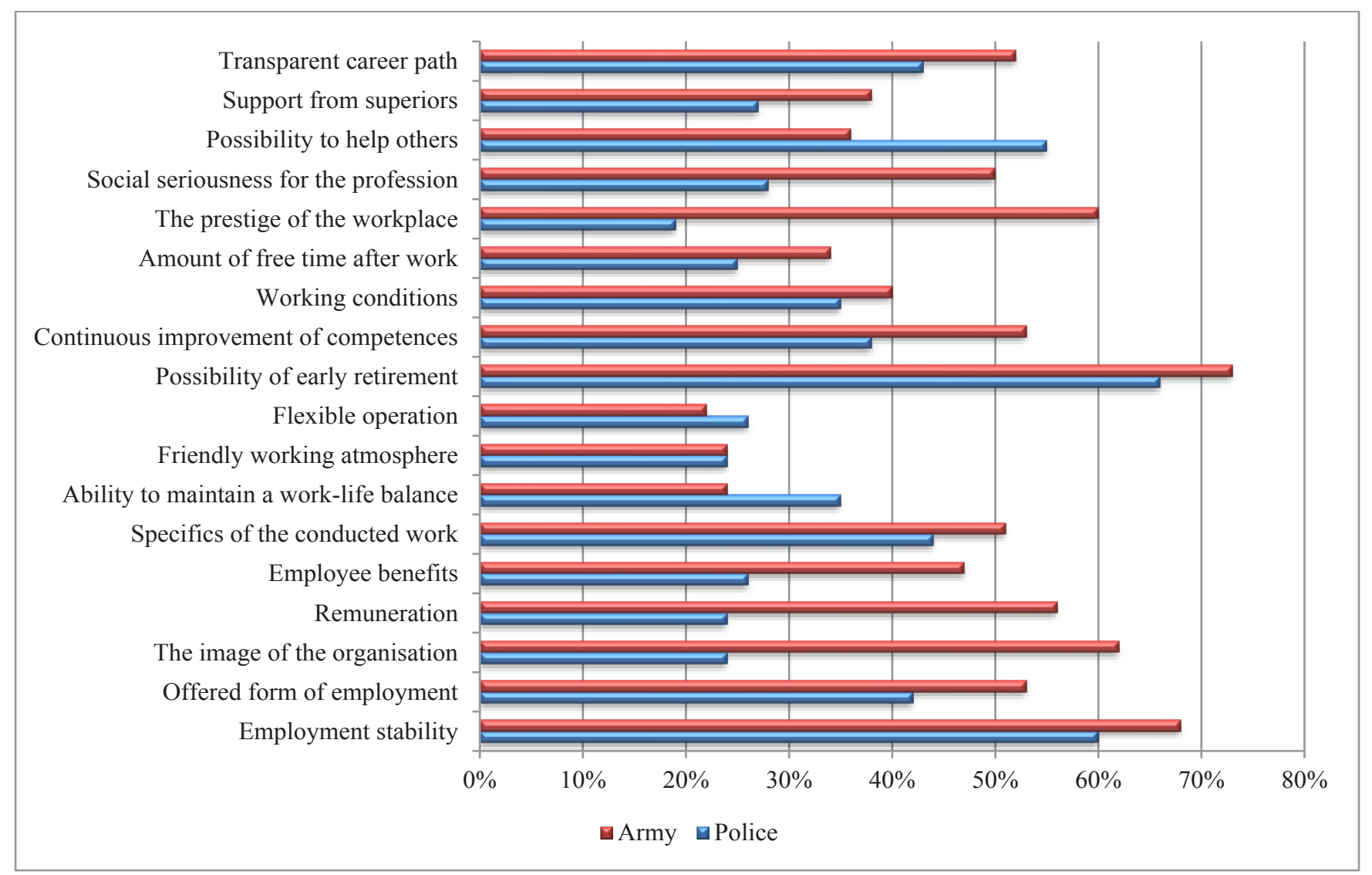

Chart 8. Factors influencing the attractiveness of uniformed services as employers

respondents) enjoys a much better image than the Police ( $17 \%$ of respondents). The assessment of the image of both these institutions also corresponds to the assessment of the Police and the Army as employers on the market (Chart 7).

According to $55 \%$ of the respondents, the military is a good and very good employer. Only $7 \%$ of respondents were of the opposite opinion. However, respondents expressed a different opinion with regard to the image of the Police - according to $21 \%$ of the respondents, the Police is a good and very good employer, which was denied by $32 \%$ of the respondents.

In order to identify the attractiveness of both institutions as employers on the Polish market, the respondents were asked to express their opinions on 18 factors that may have a positive or negative impact on the image of the Police and Army as employers. The results of the research are presented in Chart 8.

The research shows that the group of 5 most frequently indicated factors of attractiveness of the Police as employers includes: possibility of early retirement $(66 \%)$, stability of employment (60\%), possibility of helping others (55\%), content of work (44\%) and clear career path (43\%). In turn, with regard to the Army, the respondents indicated: the possibility of early retirement (73\%), stability of employment (68\%), image of the Army (62\%), prestige of the workplace (60\%) and the level of salaries offered (56\%). In conclusion, in the case of uniformed services, the important factors shaping the attractiveness of these institutions as employers are still the

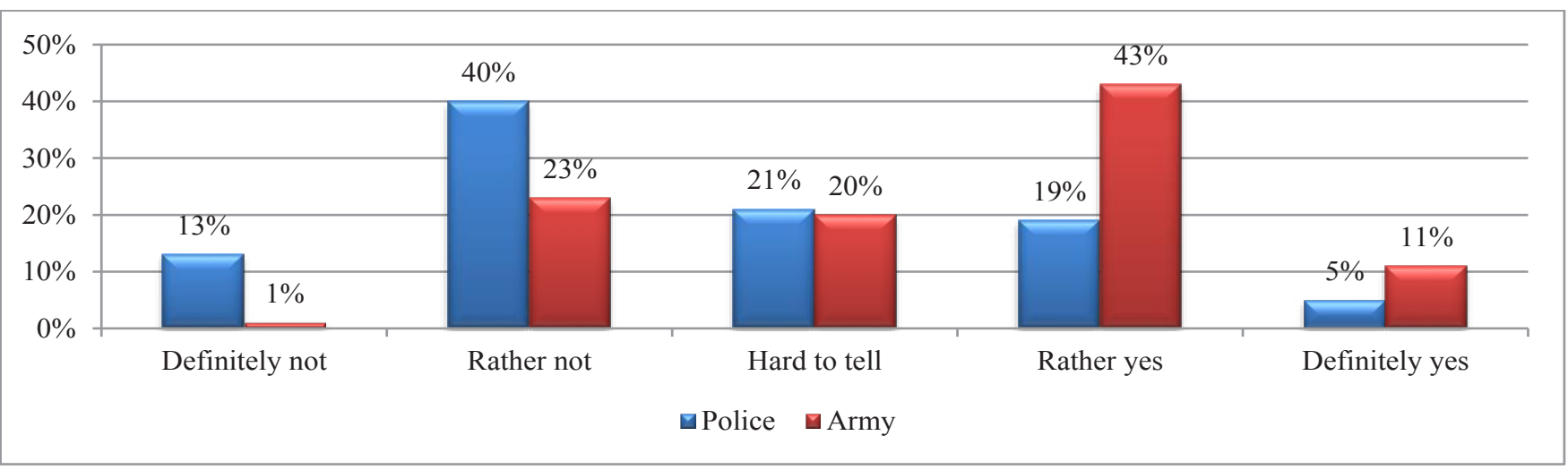

Chart 9. Difficulty in getting a job in the Police and Army according to the respondents 
privileges with respect to the possibility of early retirement, as well as the stability of the offered remuneration. Benefits in terms of salary, prestige of the profession and the image of the institution-employers were recorded in relation to the military. In the case of the Police, however, respondents more frequently point to the specifics of their work and the possibility of helping others, and thus emphasise the servile character of work related to their vocation.

The prestige of the Army as a workplace is also confirmed by the results of research on the difficulty of finding a job in both analysed institutions (Chart 9).

The difficulty of obtaining a job in the Army is confirmed by $54 \%$ of respondents (this also translates into the prestige of the service), the opposite opinion was expressed by $24 \%$ of respondents. In turn, $53 \%$ of respondents do not find it difficult to apply for a job in the Police, which was denied by $24 \%$ of the respondents. The difficulty of recruitment proceedings is an important factor determining the willingness to take up a job in a given institution. As far as the Police are concerned, although the respondents indicated the lack of such difficulties, they pointed out that the work of Police officers is not appreciated by the society (65\%), which in addition to that in connection with the amount of offered remuneration, low flexibility of work and difficulty in maintaining balance between professional and private life, reduces the attractiveness of the Police as an employer.

In conclusion, it can be stated that when analysing the needs of potential candidates for a job together with the possibilities offered by the Police and the Army, the Army wins this comparison, which is confirmed by the image of this institution, as well as by the prestige and social respect for the soldierıs profession. Poor results of the Police, both in terms of general image and employer image, explain the current situation in the Police, which is struggling to fill over 4 thousand vacancies.

\section{CONCLUSION}

To sum up, for many years the issue of globalization has been the subject of broad interest of scientists and practitioners, who not only look at the phenomenon of positive aspects affecting organisations and the labour market, but also negative aspects, which both the organisations and the labour market have to deal with, striving for unwavering development and effective use of resources, including human resources of such a high value.

There are many organisations operating on the labour market. Form the numerical standpoint, an important employer in Poland are the uniformed services, including the Police and the Polish Army. These organisations, functioning on the contemporary market, as well as organisations from the business environment, have to cope with the challenges posed by globalization, which significantly shapes the labour markets, including the demand and supply of labour and the mobility of employees, their needs and values. In this article, the author sought to answer the research problem formulated in the form of a question: how does globalization affect the situation and image of uniformed services in Poland as the employers? On the basis of the results of the conducted research it can be stated that globalization, and more precisely the effects of globalization in the form of increased mobility of employees (manifested by economic migration), a decrease in the unemployment rate, or increase in financial expectations towards employers, affect the situation and image of uniformed services as employers. This influence is not the same in relation to the Police and the Polish Army, which results from differences in perception of these institutions as employers, general image of these institutions, including social respect for the profession. While the military still enjoys both a positive overall image and a positive image as an employer and is perceived as an attractive place to work due to the possibility of an early retirement, stability of employment and the amount of remuneration offered, this situation is completely different in relation to the Police. The Police do not enjoy a positive image as an employer, but they encourage people to work in the area of early retirement, stability of employment, content of work and assistance to others, which, however, does not fully correspond to the important factors determining the choice of a future employer. With the progress of globalization, including the opening up of European labour markets, some people who want to have a future in uniformed services decide to take up service abroad, in countries with much more attractive employment conditions. Economic benefits are still the main determinant of the choice of an employer.

\section{REFERENCES}

AMB. Niemiecka policja rekrutuje Polaków! Można dostać 1,2 tys. euro miesięcznie. https://superbiz.se.pl/wiadomosci/ niemiecka-policja-rekrutuje-polakow-mozna-zarobic-12-tys-euro-miesiecznie-aa-HZMU-aRYW-82nE.html

(access 09.08.2018).

Bernstein, D. (1984). Corporate Image and Reality: A Critique of Corporate Communication. Eastbourne.

Bhargava, V. (2006). Global Issues for Global Citizens: An Introduction to Key Development Challenges. Washington.

Boorstin, D.J. (1961). The Image: A Guide to Pseudo-Events in America. New York.

Charles, S. (1996). The Policy Challenges of globalization and Regionalism. OECD. Paris.

Giddens, A. (1991). Modernity and Self-Identity. Cambridge.

https://sjp.pl/globalizacja (access 25.04.2019).

https://wkuostroda.wp.mil.pl/pl/pages/wolne-etaty-w-jw-2018-04-16-v/ (access 25.04.2019). 
Informacja o rozmiarach i kierunkach czasowej emigracji z Polski w latach 2004-2017.

https://stat.gov.pl/obszary-tematyczne/ludnosc/migracje-zagraniczne-ludnosci/ informacja-o-rozmiarach-i-kierunkachczasowej-emigracji-z-polski-w-latach-2004-2017,2,11.html (access 25.04.2019).

Levy-Livermore, A. (1998). Handbook on the globalization of the word economy. Cheltenham.

Liberska, B. (2002). Współczesne procesy globalizacji gospodarki światowej. [In] Liberska, B. Globalizacja: Mechanizmy i wyzwania. Warsaw.

Liwo, M. (2015). Służby mundurowe jako kategoria języka prawniczego. Przegląd Prawa Publicznego, no. 15.

Maciejko, W; Rojewski, M; Suławko-Karetko, A. (2011). Prawo administracyjne. Zarys wykładu części szczególnej. Warsaw.

McGrew, A. (1992). Conceptualizing Global Polices. [In] McGrew, A. Global Politics. Cambridge.

Migracje zarobkowe Polaków VIII - maj 2018, WorkService. http://www.workservice.com/pl/Centrum-prasowe/Raporty/ Raport-Migracyjny/Migracje-Zarobkowe-Polakow-VIII-maj-2018 (access 25.04.2019).

Nguyen, N; LeBlanc, G. (1998). The mediating role of corporate image: on customer's retention decision: an investigation in financial services. International Journal of Banking Marketing, Vol. 16, No. 2.

Noga, M; Stawicka, K. (2009). Rynek pracy w Polsce w dobie integracji europejskiej i globalizacji. CEDEWU.pl. Warsaw.

Ohmae, K. (1995). The End of Nation State. New York.

Robinson, R. (1992). Globalization: Social Theory and Global Culture. London.

Rzepka, A. (2014). Globalizacja w teorii i praktyce. Wydawnictwo Naukowe SILVA RERUM. Poznań.

Scholte, J.A. (2006). Globalizacja. Krytyczne wprowadzenie. Sosnowiec.

Skowronek, I. (2012). Marketing doświadczeń. Od doświadczeń klienta do wizerunku firmy. Wydawnictwo Poltext. Warsaw.

Sławik K., Zarys systemu prawa policyjnego, Warsaw 2011. Stan zatrudnienia na dzień 1 stycznia 2019 roku. http://www.info. policja.pl/inf/organizacja/stan-zatrudnienia/49216,Stan-zatrudnienia-na-dzien-1-stycznia-2019-roku.html (access dnia 25.04.2019).

Stopa bezrobocia rejestrowanego w latach 1990-2019. https://stat.gov.pl/obszary-tematyczne/rynek-pracy/bezrobocierejestrowane/stopa-bezrobocia-rejestrowanego-w-latach-1990-2019,4,1.html (access 25.04.2019).

Sutor, A. (2018). Porównanie wynagrodzeń w Warszawie i w Krakowie w 2018 r. https://wynagrodzenia.pl/artykul/ porownanie-wynagrodzen-w-warszawie-i-krakowie-w-2018-roku (access 25.04.219).

Swobodny przepływ pracowników. http://www.europarl.europa.eu/factsheets/pl/sheet/41/swobodny-przeplywpracownikow (access 25.04.2019). The Organization's External Environment. https://cnx.org/contents/ w6yyq31c@2.11:nGuf NJoq@2/4-1-The-Organization-s-External-Environment (access 04.05.2019).

Waszkiewicz, A. (2011). Wizerunek organizacji. Teoria i praktyka badania wizerunku uczelni. Instytut Dziennikarstwa Uniwersytetu Warszawskiego. Warsaw.

Wojska Obrony Terytorialnej. https://www.gov.pl/web/obrona-narodowa/wojska-obrony-terytorialnej (access 25.04.2019).

Wojtaszczyk, K. (2012). Employer branding czyli zarządzanie marką pracodawcy. Uwarunkowania, procesy, pomiar. Wydawnictwo Uniwersytetu Łódzkiego. Łódź.

Zarobki Policjantów w 2018 r. http://www.info.policja.pl/inf/organizacja/zarobki-policjantow/164134,Zarobki-policjantow2018-r.html (access 25.04.2019). 